\title{
Leaf Gas Exchange Response of 'Arapaho' Blackberry and Six Red Raspberry Cultivars to Moderate and High Temperatures
}

\author{
Eric T. Stafne ${ }^{1}$, John R. Clark ${ }^{2}$, and Curt R. Rom ${ }^{3}$ \\ Department of Horticulture, University of Arkansas, Fayetteville, AR 72701
}

Additional index words. evapotranspiration, heat tolerance, net $\mathrm{CO}_{2}$ assimilation, Rubus idaeus, stomatal conductance

Abstract. Leaf gas exchange of six red raspberry (Rubus idaeus L.) and one blackberry (Rubus L. subgenus Rubus Watson) genotypes growing in 12-L containers was measured at four temperatures $\left(20,25,30\right.$, and $\left.35^{\circ} \mathrm{C}\right)$ once a month for 3 months in growth chambers by infrared gas analysis. Measurements were taken on three successive leaves on the same primocane between the third and seventh nodes ( $\approx 75 \%$ to $85 \%$ of full leaf expansion). The plants were grown in ambient (field) conditions except when measurements were taken. Maximum daily ambient temperatures rose as high as $\approx 37^{\circ} \mathrm{C}$ during this period. $\mathrm{Net}^{\mathrm{CO}_{2}}$ assimilation (A), evapotranspiration (ET), and stomatal conductance $\left(g_{s}\right)$ were measured during June, July, and August. Significant differences $(P \leq 0.01)$ in A were found among the seven genotypes. 'Arapaho' blackberry displayed the highest mean $\mathrm{A}$ rate at all temperatures. Only in the raspberry cultivars Nova and Reveille did the rate of A drop significantly when temperature increased from 20 to $30^{\circ} \mathrm{C}$. 'Reveille' was also the only cultivar in which A significantly declined between 30 and $35{ }^{\circ} \mathrm{C}$. The ET increased significantly over the four temperatures in four cultivars ('Arapaho', 'Heritage', 'Nova', and 'Southland'). The ET rate at $35^{\circ} \mathrm{C}$ was higher for 'Arapaho' than for all other cultivars. 'Autumn Bliss', 'Dormanred', and 'Reveille' did not change significantly as the temperature rose from 20 to $35^{\circ} \mathrm{C}$. Stomatal conductance of 'Heritage' and 'Arapaho' did not change significantly between 20 and $35^{\circ} \mathrm{C}$, whereas that of 'Autumn Bliss' and 'Reveille' declined almost $50 \%$ when temperature increased to 30 or $35^{\circ} \mathrm{C}$.

Interest in red raspberry production has grown in the southern states in recent years (Clark and Rom, 1997). However, there are no commercially viable, southern-adapted cultivars available to satisfy the increasing demand (Moore, 1997). Most cultivars have been bred in cooler, more northerly areas and have limited adaptation in the South, where high temperatures pose serious problems. Additional obstacles are loss of hardiness due to fluctuating winter temperatures, disease, and high light intensities (Hull, 1961; Lawrence, 1980; Moore, 1997).

Few studies on red raspberry have focused on the leaf gas exchange capabilities at high temperatures. Fernandez and Pritts (1994) observed that $\mathrm{CO}_{2}$ assimilation (A) declined in both floricane and primocane leaves of potted 'Titan' red raspberry as temperature increased,

Received for publication 7 Apr. 2000. Accepted for publication 10 Apr. 2001. Published with approval of the Director, Arkansas Agricultural Experiment Station, manuscript no. 99113. This paper is a portion of a thesis submitted by Eric T. Stafne. The cost of publishing this paper was defrayed in part by the payment of page charges. Under postal regulations, this paper therefore must be hereby marked advertisement solely to indicate this fact.

${ }^{1}$ Research Specialist. E-mail: estafne@uark.edu ${ }^{2}$ Professor.

${ }^{3}$ Associate Professor. with primocane leaves exhibiting higher $\mathrm{A}$ rates at all temperature levels. At $30^{\circ} \mathrm{C}$, A in primocane leaves was nearly $6 \mu \mathrm{mol} \cdot \mathrm{m}^{-2} \cdot \mathrm{s}^{-1}$. As temperature increased to $35^{\circ} \mathrm{C}$, A declined to $\approx 4 \mu \mathrm{mol} \cdot \mathrm{m}^{-2} \cdot \mathrm{s}^{-1}$ and at $40{ }^{\circ} \mathrm{C}$ it dropped to around $2 \mu \mathrm{mol} \cdot \mathrm{m}^{-2} \cdot \mathrm{s}^{-1}$. Percival et al. (1996) found that an air temperature of $35^{\circ} \mathrm{C}$ yielded a whole-plant A rate of $\approx 4 \mu \mathrm{mol} \cdot \mathrm{m}^{-2} \cdot \mathrm{s}^{-1}$ in 'Heritage'. They concluded that maximum A was reached between 17 and $20^{\circ} \mathrm{C}$, while temperatures above $20^{\circ} \mathrm{C}$ reduced it. Privé et al. (1997) reported that high net carbon exchange rates could be attained at warm temperatures $\left(25\right.$ to $\left.30{ }^{\circ} \mathrm{C}\right)$ in potted 'Autumn Bliss'. The objective of our study was to assess the gas exchange capabilities of a broader range of Rubus germplasm over moderate to high temperatures.
Dormant plants from virus-tested stock of red raspberry cultivars were obtained from two local nurseries: Pense Nurseries and Simmons Berry Farm, both in Mountainburg, Ark. The blackberry plants were obtained from the University of Arkansas Agricultural Research and Extension Center, Fayetteville (Table 1). The first 'Arapaho' plants did not produce any growth, and were replaced with 1-month-old plants 1 month later.

Thirty-five total plants were potted in 12-L pots with a Universal Mix media (Strong-Lite Hort. Prod., Pine Bluff, Ark.) and a controlledrelease fertilizer (Osmocote 18N-2.6P-9.9K, $51 \mathrm{~g} / \mathrm{pot}$ ) on 17 Apr. 1998 and placed in ambient field conditions on the same day at Fayetteville, Ark. There were five replications per cultivar, with a block consisting of a single plant of each cultivar. They were drip irrigated at the rate of 4-L per hour for $1 \mathrm{~h}$ per day from 0800 to 0900 HR. Plants were also watered to saturation the night before measurements were taken. Beginning in June, leaf gas exchange measurements were undertaken. These consisted of $\mathrm{CO}_{2}$ assimilation (A), evapotranspiration (ET), and stomatal conductance $\left(g_{s}\right)$. On the morning of the day measurements were to be taken, one block of pots was transported to the Rosen Alternative Pest Control Center (APC) building and placed in a $70 \times 105 \times 70$ $\mathrm{cm}$ (height $\times$ width $\times$ depth) growth chamber (Conviron 3244, Winnipeg, Manitoba, Canada) at a randomly selected temperature of 20,25, 30 , or $35{ }^{\circ} \mathrm{C}$. The plants were allowed to acclimate to the temperature for $1 \mathrm{~h}$ before any measurements were taken (Fernandez and Pritts, 1994; Moon et al., 1987). Lighting was provided inside the growth chamber, but humidity could not be controlled. A CIRAS-1 portable infrared gas analyzer (PP-Systems; Hitchens, Herts, U.K.) with a Parkinson leaf cuvette $\left(2.5 \mathrm{~cm}^{2}\right)$ was used to take gas exchange measurements. The cuvette temperature was set at the same temperature as that of the growth chamber. Leaf and cuvette temperatures were maintained by a thermoconductive peltier plate and measured using an infrared temperature sensor. Photosynthetically active radiation $(P A R)$ was set at 1500 $\mu \mathrm{mol} \cdot \mathrm{m}^{-2} \cdot \mathrm{s}^{-1}$, considered a saturating light level for raspberries (Fernandez and Pritts, 1994; Hunt et al., 1991; Rom and Clark, 1991). The air flow rate inside the cuvette was set at 200 $\mathrm{mL} \cdot \mathrm{min}^{-1}$ with $350 \mathrm{~mL} \cdot \mathrm{L}^{-1} \mathrm{CO}_{2}$ and $50 \%$ of ambient water vapor.

Table 1. Origin and parentage of cultivars used in this study.

\begin{tabular}{|c|c|c|}
\hline Cultivar & Origin & Parentage \\
\hline Arapaho & Clarksville, Ark. & Ark. 631 x Ark. 883 (Moore and Clark, 1993) \\
\hline Autumn Bliss & East Malling, England & $\begin{array}{l}\text { Complex involving } R \text {. strigosus Michx., } R \text {. } \\
\text { arcticus L., } R \text {. occidentalis L. and several red } \\
\text { raspberry cultivars (Keep et al., 1984) }\end{array}$ \\
\hline Dormanred & State College, Miss. & R. parvifolius $\times$ Dorsett (Overcash, 1972) \\
\hline Heritage & Geneva, N.Y. & (Milton x Cuthbert) x Durham (Ourecky, 1969) \\
\hline Nova & Kentville, Nova Scotia & Southland $x$ Boyne (Brooks and Olmo, 1983) \\
\hline Reveille & College Park, Md. & $\begin{array}{l}\text { [VPI } 1 \text { (Indian Summer X Sunrise)] x September } \\
\quad(\text { Brooks and Olmo, 1968) }\end{array}$ \\
\hline Southland & Raleigh, N.C. & N.C. 237 x Md. S420-5 (Hull, 1969) \\
\hline
\end{tabular}


Measurements were taken on five consecutive days during a 1-week period, with one block measured per day, during 23-27 June, 20-24 July, and 17-21 Aug. For each plant, data for three individual leaves on one primocane were averaged for each temperature. Leaves were $\approx 75 \%$ to $85 \%$ of full expansion, from the third to the seventh node. Measurements were taken between 0800 and 1230 HR to avoid any diurnal response, which has been reported in raspberry (Fernandez and Pritts, 1994; Hunt et al., 1991; Klauer et al., 1992).

A total of three growth chambers were used: the first to allow the plants to acclimate to the desired temperature $(1 \mathrm{~h})$, the second to measure the gas exchange (one pot at a time), and the third to allow the plants to acclimate to the next randomly selected temperature to be measured. Once a plant was measured, it was immediately placed into the next growth chamber for acclimation. Plants were rotated until gas exchange had been measured at all temperatures for each cultivar, then the block of plants was taken back to the field.

The design of the study was a randomized complete block with five replications per cultivar. The data were analyzed as a split-plot in time for A, ET, and $g_{s}$. Fixed effects were cultivar, temperature, month, and all interactions involving these effects. Random effects were block, interactions involving block, and residual error. The data analysis was performed with the Statistical Analysis Systems Program (SAS Institute, 1989). Analysis of variance was calculated by the MIXED procedure and mean separation was by $t$ test at $P \leq$ 0.01 . Trend analysis was done using the contrast statement in the MIXED procedure.

\section{Results}

Previous reports for both primocane-fruiting (Privé et al., 1997) and floricane-fruiting (Fernandez and Pritts, 1994) potted field-grown raspberries indicated that leaf gas exchange was constant throughout the growing season on primocane leaves. Privé et al (1997) also found that fruiting did not affect leaf gas exchange in 'Autumn Bliss' primocanes. In the current study, leaf gas exchange measurements were taken only on primocane leaves, thus avoiding seasonal fluctuations reported on floricane leaves (Fernandez and Pritts, 1994).

For all three dependent variables (A, ET, and $\left.g_{s}\right)$, the cultivar $\times$ temperature interaction was significant $(P \leq 0.01)$. There was also a significant interaction of month $\times$ temperature for ET. No other interactions were significant for any of the dependent variables.

Assimilation rates at temperatures of 20 to $25{ }^{\circ} \mathrm{C}$ (Table 2) for all cultivars except 'Dormanred' were within rates (6 to 12 $\left.\mu \mathrm{mol} \cdot \mathrm{m}^{-2} \cdot \mathrm{s}^{-1}\right)$ reported by other researchers (Donnelly and Vidaver, 1984; Fernandez and Pritts, 1994; Klauer et al., 1992). 'Arapaho' displayed higher A rates than the raspberry cultivars in accordance with previous findings (Andersen, 1989; Rom and Clark, 1991).

Similar declines in A were observed for all cultivars as temperature increased above 25 ${ }^{\circ} \mathrm{C}$ (Table 2), even though A rates were not identical for all cultivars. The A rates of all genotypes was highest at 20 or $25^{\circ} \mathrm{C}$. The average decline among raspberries was $40 \%$ between 20 and $35^{\circ} \mathrm{C}$, with the rate in 'Reveille' declining nearly $50 \%$. No other raspberry cultivar had as significant a decline. In contrast, the blackberry 'Arapaho' exhibited only a $22 \%$ decline in A rate as temperature rose $25^{\circ} \mathrm{C}$ to $35^{\circ} \mathrm{C}$.

Significant variation in A occurred among the cultivars at a given temperature (Table 2). At $20^{\circ} \mathrm{C}$, 'Arapaho' and 'Reveille' had the highest A rates, while 'Dormanred', 'Heritage', and 'Autumn Bliss' had the lowest rates.

Trend analysis across all cultivars showed a negative linear relationship between $\mathrm{A}$ and temperature $(P \leq 0.0001)$. This was expected as similar results were reported by other researchers (Fernandez and Pritts, 1994). Individual cultivar trend analysis showed a negative linear relationship for all raspberries reflecting lower A rate with increased temperature (Table 3). Contrast trend analysis comparisons among cultivars revealed that the slopes were not significantly different except for those involving 'Reveille', which had a slope similar only to 'Southland (data not shown). Response in 'Arapaho' was quadratic probably because of the increase between 20 and $25^{\circ} \mathrm{C}$ prior to a decline between 25 and 35 ${ }^{\circ} \mathrm{C}$ (Table 2).

The ET rates observed in this study across all temperatures were within the range ( 2 to 6 $\left.\mathrm{mmol} \cdot \mathrm{m}^{-2} \cdot \mathrm{s}^{-1}\right)$ reported by other researchers for red raspberry (Cameron and Hartley, 1989) and blackberry cultivars (Andersen, 1989). Similar increases in ET were observed with increasing temperature for the blackberry cultivar Arapaho, and the red raspberry cultivars Heritage, Nova, and Southland (Table 2). Although small increases in ET were observed in 'Autumn Bliss', 'Dormanred', and 'Reveille', they were not significant. The increase in 'Arapaho' (52\%) was especially dramatic over the temperature range used in this study. In comparison, 'Southland' was the red raspberry cultivar with the greatest increase in ET (38\%).

Cultivar by temperature analysis indicated that all cultivars were similar in ET at 20 and $25{ }^{\circ} \mathrm{C}$, except 'Dormanred' in which ET remained constant (Table 2). At $30^{\circ} \mathrm{C}$, the ET rate of 'Arapaho' was greater than those of all raspberry cultivars except 'Heritage', 'Nova', and 'Southland'; at $35^{\circ} \mathrm{C}$ it was significantly higher than those of all raspberry cultivars.

Trend analysis revealed positive linear relationships between temperature and mean ET for all cultivars $(P \leq 0.0001)$. Individual cultivar trend analysis determined that 'Arapaho', 'Heritage', 'Nova', and 'Southland' had positive linear relationships with temperature. The other individual cultivars displayed no significant trend for ET (Table 3).

Differences in ET among temperatures in June were significant (Table 4); however, in July, $20{ }^{\circ} \mathrm{C}$ differed only from 30 and $35^{\circ} \mathrm{C}$. There were no significant differences among temperatures in August.

No differences in ET were observed at 20 ${ }^{\circ} \mathrm{C}$ among months (Table 4), but at $25{ }^{\circ} \mathrm{C}$, values for June were significantly higher than those for July or August. The ET rates at $30^{\circ} \mathrm{C}$ differed among all months, with higher values in June and lowest values in August. At $35^{\circ} \mathrm{C}$,

Table 2. Effects of temperature and Rubus genotype on mean $\mathrm{CO}_{2}$ assimilation (A), evapotranspiration (ET), and stomatal conductance $\left(g_{s}\right)$ over 3 months.

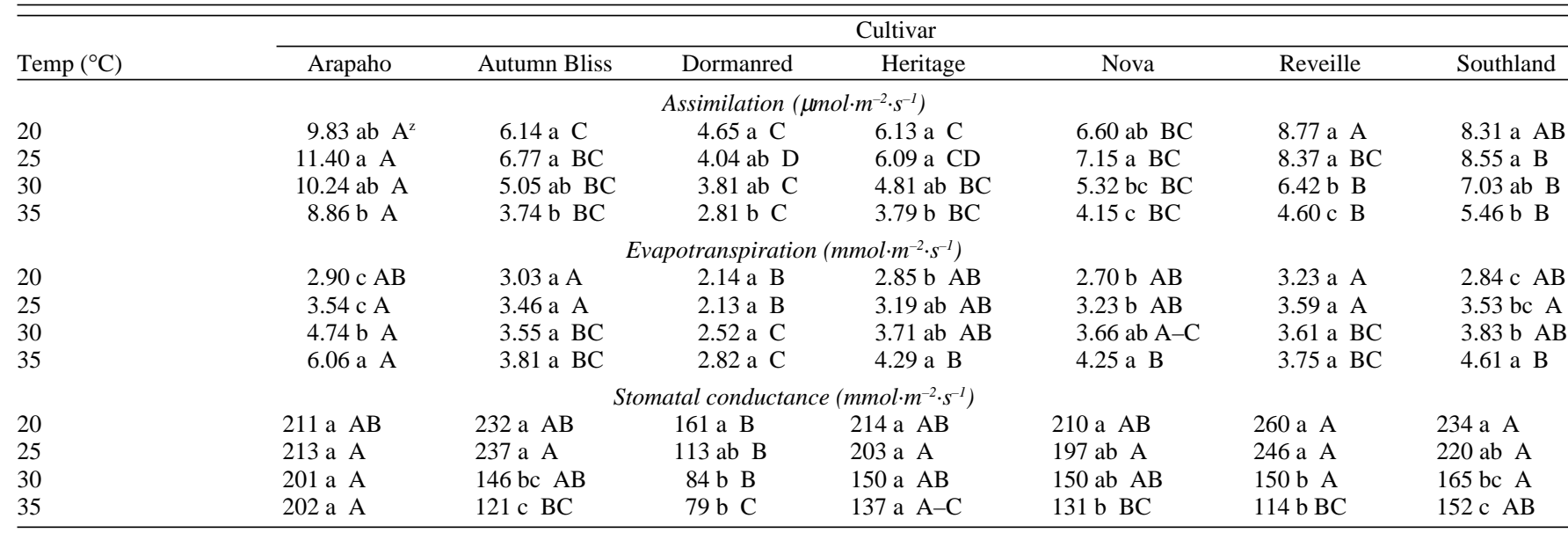

${ }^{2}$ Significant differences among temperatures within cultivars are indicated by lower case letters. Significant differences among cultivars within temperatures are indicated by uppercase letters. Means with the same letter are not significantly different as determined by $t$ test, $P \leq 0.01$. 
Table 3. Significance of $\mathrm{F}$ in cultivar trend analysis across month and temperature for $\mathrm{CO}_{2}$ assimilation (A), evapotranspiration (ET), and stomatal conductance $\left(g_{s}\right)$.

\begin{tabular}{llccc}
\hline \hline Cultivar & Trend & $\mathrm{A}$ & $\mathrm{ET}$ & $g_{s}$ \\
\hline Arapaho & Linear & $\mathrm{NS}^{\mathrm{z}}$ & 0.0001 & $\mathrm{NS}$ \\
& Quadratic & 0.0010 & $\mathrm{NS}$ & $\mathrm{NS}$ \\
Autumn Bliss & Linear & 0.0001 & $\mathrm{NS}$ & 0.0001 \\
& Quadratic & $\mathrm{NS}$ & $\mathrm{NS}$ & $\mathrm{NS}$ \\
Dormanred & Linear & 0.0036 & $\mathrm{NS}$ & 0.0001 \\
& Quadratic & $\mathrm{NS}$ & $\mathrm{NS}$ & $\mathrm{NS}$ \\
Heritage & Linear & 0.0010 & 0.0009 & 0.0051 \\
& Quadratic & $\mathrm{NS}$ & $\mathrm{NS}$ \\
Nova & Linear & 0.0001 & 0.0001 & $\mathrm{NS}$ \\
& Quadratic & $\mathrm{NS}$ & $\mathrm{NS}$ & 0.0012 \\
Reveille & Linear & 0.0001 & $\mathrm{NS}$ & $\mathrm{NS}$ \\
& Quadratic & $\mathrm{NS}$ & $\mathrm{NS}$ & 0.0001 \\
Southland & Linear & 0.0001 & 0.0001 & $\mathrm{NS}$ \\
& Quadratic & $\mathrm{NS}$ & $\mathrm{NS}$ & 0.0001 \\
& & & & $\mathrm{NS}$ \\
\hline
\end{tabular}

${ }^{\mathrm{N}}$ Nonsignificant $(P \leq 0.01)$.

ET values in June were significantly different from those in July and August, but the differences between July and August values were not significant.

Stomatal conductance rates measured in our study were similar to those reported in other studies of red raspberry (Cameron and Hartley, 1989; Privé et al., 1997) and blackberry cultivars (Andersen, 1989). All raspberries except 'Heritage' showed significant declines in $g_{s}$ as temperatures increased (Table 2), with 'Dormanred', 'Autumn Bliss', and 'Reveille' showing the sharpest declines $(51 \%$, $49 \%$, and $46 \%$, respectively). 'Arapaho' showed no significant differences in $g_{s}$ over the temperature range 20 to $35^{\circ} \mathrm{C}$.

At each temperature, $g_{s}$ varied significantly among cultivars (Table 2). 'Dormanred' had the lowest $g_{s}$ at all temperatures. At $20^{\circ} \mathrm{C}$, only 'Reveille' and 'Southland' had values significantly higher than that of 'Dormanred', but at $25^{\circ} \mathrm{C}$, values for all cultivars were significantly higher than that of 'Dormanred'. 'Arapaho' had the highest $g_{s}$ at $30^{\circ} \mathrm{C}$, though it was not significantly different from any of the raspberries except 'Dormanred'. 'Arapaho', 'Southland', and 'Heritage' had the highest $g_{s}$ at $35^{\circ} \mathrm{C}$.

Trend analysis indicated a negative linear relationship between $g_{s}$ and temperature $(P \leq$ $0.0001)$ for each raspberry cultivar and for the mean of all cultivars, whereas (Table 3 ), the blackberry 'Arapaho' showed no significant regression response for $g_{s}$.

Assimilation trends and rates at high temperatures observed in our study were consistent with the results of other researchers (Fernandez and Pritts, 1994; Percival et al., 1996). All cultivars experienced declines in A as temperature increased from 25 to $35^{\circ} \mathrm{C}$ and the decreases were nearly parallel for all cultivars of both red raspberry and blackberry. These findings support the data presented elsewhere in the literature for heat tolerance of temperate fruit crops (Hancock et al., 1992; Sams and Flore, 1982).

Differences in A were observed between the red raspberries and the blackberry. 'Arapaho' showed a dramatic increase in A from 20 to $25{ }^{\circ} \mathrm{C}$, suggesting a potentially higher temperature optimum for $\mathrm{A}$ than in red raspberries (Cameron et al., 1993; Percival et al., 1996). However, $g_{s}$ remained stable from
20 to $35^{\circ} \mathrm{C}$ for this blackberry, suggesting that $g_{s}$ is not acting as a limiting factor to A at temperatures up to $35^{\circ} \mathrm{C}$. Similar results have been observed in heat-adapted Ilex sp. (Ranney and Ruter, 1997). The extreme increase in ET as temperature increased is probably due to the large vapor pressure deficit (VPD) that was created as temperature rose, but the relative humidity remained constant.

The red raspberry 'Reveille', which has been recommended for southern conditions (Swartz et al., 1992) though not bred in the deep South, showed a precipitous decline in both A and $g_{s}$, but no significant difference in ET at higher temperatures. This lack of an increase in ET would result in insufficient evaporative cooling, creating a higher leaf temperature, which in turn could have led to the strong declines in $\mathrm{A}$ and $g_{s}$. The same trends were seen in 'Autumn Bliss', where A and $g_{s}$ decreased, but ET was not significantly affected by temperature. This may reflect the fact that 'Autumn Bliss' originated in the United Kingdom which has a cool climate without extreme temperatures.

'Dormanred', a southern-adapted red raspberry, displayed the lowest A rates. Stomatal conductance for 'Dormanred' decreased as A decreased; however, the decline was greater for $g_{s}$. Evapotranspiration was not affected significantly by temperature. If reasoning is consistent with the conclusions made for 'Reveille' and 'Autumn Bliss', then a higher leaf temperature could result and similar declines in A and $g_{s}$ would be observed. However, the decline of $\mathrm{A}$ in 'Dormanred' was small in comparison with the decline in 'Reveille'. This may reflect a different adaptation mechanism of 'Dormanred' to high temperatures than in other red raspberry cultivars.

'Heritage' is a widely adapted, primocanefruiting red raspberry that has been grown in the upper South. It displayed moderate A rates in comparison with the other raspberry cultivars in this study. Stomatal conductance did not differ with temperature, suggesting that it sustains relatively constant stomatal function in various temperature regimes, which could explain its wide area of adaptation. 'Nova', along with its parent 'Southland', performed in a very similar manner to 'Heritage'. This is mildly surprising since 'Southland' is a southern-adapted cultivar (Moore, 1997), but 'Nova'

Table 4. Evapotranspiration (ET) $\left(\mathrm{mmol} \cdot \mathrm{m}^{-2} \cdot \mathrm{s}^{-1}\right)$ for 3 months and four temperatures averaged over seven Rubus genotypes.

\begin{tabular}{llcc}
\hline & \multicolumn{4}{c}{ Month } \\
\cline { 2 - 4 } Temp $\left({ }^{\circ} \mathrm{C}\right)$ & June & July & August \\
\hline 20 & $3.38 \mathrm{~d} \mathrm{~A}^{\mathrm{z}}$ & $2.49 \mathrm{~b} \mathrm{~A}$ & $2.57 \mathrm{a} \mathrm{A}$ \\
25 & $4.28 \mathrm{c} \mathrm{A}$ & $2.97 \mathrm{abB}$ & $2.47 \mathrm{a} \mathrm{B}$ \\
30 & $5.26 \mathrm{~b} \mathrm{~A}$ & $3.43 \mathrm{a} \mathrm{B}$ & $2.31 \mathrm{a} \mathrm{C}$ \\
35 & $6.50 \mathrm{a} \mathrm{A}$ & $3.53 \mathrm{a} \mathrm{B}$ & $2.64 \mathrm{a} \mathrm{B}$ \\
\hline z
\end{tabular}
months are indicated by lowercase letters. Significant differences among months within temperatures are indicated by uppercase letters. Means with the same letter are not significantly different as determined by $t$ test, $P \geq 0.01$.

has 'Boyne' in its ancestry, a northern-adapted cultivar from Canada.

Distinct groupings of genotypes and their responses to elevated temperatures were detected in this study. However, all cultivars had similar A, ET and $g_{s}$ responses to high temperatures. No cultivars were found to adapt to heat simply through the measurements reported, although acclimation may be seen in the ET rates as months progressed. Adaptation to heat is probably related to gas exchange processes, but our study suggests that other factors play a more important role.

\section{Literature Cited}

Andersen, P.C. 1989. Leaf gas exchange of eleven species of fruit crops in north Florida. Proc. Fla. State Hort. Soc. 102:229-234.

Brooks, R.M. and H.P. Olmo. 1968. Register of new fruit and nut varieties list 23. Proc. Amer. Soc. Hort. Sci. 93:891-892.

Brooks, R.M. and H.P. Olmo. 1983. Register of new fruit and nut varieties list 33. HortScience 18:160

Cameron, J.S. and C.A. Hartley. 1989. The influence of leaf:fruit ratio on gas exchange characteristics of red raspberry leaves. Acta Hort. 262:255-258

Cameron, J.S., S.F. Klauer, and C. Chen. 1993. Development and environmental influences on the photosynthetic biology of red raspberry $(R u-$ bus idaeus L.). Acta Hort. 352:113-120.

Clark, J.R. and C.R. Rom. 1997. Introduction to the workshop: Small fruit breeding for the southern United States: Progress and prospects. Fruit Var. J. 51:133-134.

Donnelly, D.J. and W.E. Vidaver. 1984. Pigment content and gas exchange of red raspberry in vitro and ex vitro. J. Amer. Soc. Hort. Sci. 109:177-181.

Fernandez, G.E. and M.P. Pritts. 1994. Growth, carbon acquisition, and source-sink relationships in 'Titan' red raspberry. J. Amer. Soc. Hort. Sci. 119:1163-1168.

Hancock, J.F., K. Haghighi, S.L. Krebs, J.A. Flore, and A.D. Draper. 1992. Photosynthetic heat stability in highbush blueberry and the possibility of genetic improvement. HortScience 27:1111-1112.

Hull, J.W. 1961. Progress in developing red raspberries for the South. Fruit Var. Hort. Dig. 16:1314.

Hull, J.W. 1969. Southland red raspberry-A new fruit crop for the South. Fruit Var. Hort. Dig 23:48.

Hunt, S.K., D.E. Deyton, and C.E. Sams. 1991. The influence of leaf position, age, and environmen- 
tal factors on net photosynthesis of red raspberry. HortScience 26:69. (Abstr.)

Keep, E., J.H. Parker, and V.H. Knight. 1984. 'Autumn Bliss', a new early autumn-fruiting raspberry. Annu. Rpt. E. Malling Res. Sta. for 1983 p. 191-192.

Klauer, S.F., C. Chen, P.F. Foote, and J.S. Cameron. 1992. Diurnal photosynthesis and starch deposition in leaves of fruiting and deflowered red raspberry canes. HortScience 27:654. (Abstr.)

Lawrence, F.J. 1980. The current status of red raspberry cultivars in the United States and Canada. Fruit Var. J. 34:84-89.

Moore, J.N. 1997. Blackberries and raspberries in the southern United States: Yesterday, today, and tomorrow. Fruit Var. J. 51:148-157.

Moore, J.N. and J.R. Clark. 1993. 'Arapaho' erect, thornless blackberry. HortScience 28:861-862

Ourecky, D.K. 1969. 'Heritage', a new fall-bearing red raspberry. Fruit Var. Hort. Dig. 23:78.

Overcash, J.P. 1972. Dormanred raspberry: New variety for Mississippi. Bul. Mississippi Sta. Univ. 793

Percival, D.C., J.T.A. Proctor, and M.J. Tsujita. 1996. Whole-plant net $\mathrm{CO}_{2}$ exchange of raspberry as influenced by air and root-zone temperature, $\mathrm{CO}_{2}$ concentration, irradiation, and humidity. J. Amer. Soc. Hort. Sci. 121:838-845.

Privé, J-P., J.A. Sullivan, and J.T.A. Proctor. 1997. Seasonal changes in net carbon dioxide exchange rates of 'Autumn Bliss', a primocanefruiting red raspberry (Rubus idaeus L.). Can. J. Plant Sci. 77:427-431.

Ranney, T.G. and J.M. Ruter. 1997. Foliar heat tolerance of three holly species (Ilex spp.): Responses of chlorophyll fluorescence and leaf gas exchange to supraoptimal leaf temperatures. J. Amer. Soc. Hort. Sci. 122:499-503.

Rom, C.R. and J.R. Clark. 1991. Gas exchange characteristics of field-grown 'Shawnee' blackberry. HortScience 26:687-688. (Abstr.)

Sams, C.E. and J.A. Flore. 1982. The influence of age, position, and environmental variables on net photosynthesis rate of sour cherry leaves. J. Amer. Soc. Hort. Sci. 107:339-344.

SAS Institute. 1989. SAS/STAT user's guide. Release 6.03 ed. SAS Inst. Cary, N.C.

Swartz, H.J., S.K. Naess, J. Fiola, H. Stiles, B. Smith, M. Pritts, J.C. Sanford, and K. Maloney. 1992. Raspberry genotypes for the East Coast. Fruit Var. J. 46:212-216. 